\title{
MODELLING THE NUMBER OF NEW PULMONARY TUBERCULOSIS CASES WITH GEOGRAPHICALLY WEIGHTED NEGATIVE BINOMIAL REGRESSION METHOD*
}

\author{
Tsuraya Mumtaz ${ }^{1 \ddagger}$ and Agung Priyo Utomo ${ }^{2}$ \\ ${ }^{1}$ Majoring in Statistics, Sekolah Tinggi Ilmu Statistik, Indonesia, tsurayamumtaz7@gmail.com \\ 2Majoring in Statistics, Sekolah Tinggi IImu Statistik, Indonesia, agung@stis.ac.id \\ ‡corresponding author
}

Indonesian Journal of Statistics and Its Applications (eISSN:2599-0802)

Vol 2 No 2 (2018), 77 - 92

Copyright (c) 2018 Tsuraya Mumtaz and Agung Priyo Utomo. This is an open-access article distributed under the Creative Commons Attribution License, which permits unrestricted use, distribution, and reproduction in any medium, provided the original work is properly cited.

\begin{abstract}
Tuberculosis (TB) is an infectious disease caused by Mycobacterium Tuberculosis. Untill now, TB is still one of the main problems in many countries, especially developing countries. Indonesia ranked second as the country with the highest TB cases in the world in 2015, where most cases were found in Java. This study was conducted to model the number of new pulmonary TB cases in Java by considering the spatial aspects using Geographically Weighted Negative Binomial Regression (GWNBR). GWNBR method was chosen because the data used in this study were overdispered. The result showed that the population density and percentage of healthy homes were not significantly influential in each region. While the number of community health center (Puskesmas), the percentage of smokers, the percentage of households with good PHBS, the percentage of diabetes mellitus sufferer, and the percentage of people with less IMT were significant in some regions. In general, the GWNBR model was better for modelling the number of new pulmonary TB cases than negative binomial regression and GWPR.
\end{abstract}

Keywords: GWNBR, spatial, overdispersion, pulmonary tuberculosis.

\section{Introduction}

Tuberculosis is an infectious disease caused by Mycobacterium Tuberculosis. This bacteria is transmitted through the air (droplet nuclei) when a sputum from tuberculosis patient is inhaled by the others (Widoyono, 2008). Most of the tuberculosis bacteria attack the lung organ (90 percent), but can also attack other

\footnotetext{
* Received Oct 2018; Accepted Oct 2018; Published online on Nov 2018
} 
organs (Suarni, 2009). This disease has been afflicted nearly by one-third of the world's population and stated as a Global Emergency by WHO. In 2015, 10.4 million new pulmonary tuberculosis cases were found in the world and 10 percent among them have been died. Therefore, tuberculosis was considered as the second most deadly infectious disease in the world after HIV (World Health Organization, 2016).

In the same year, Indonesia rose to the second place as the country with the highest number of pulmonary tuberculosis cases in the world, reaching 10 percent of the total cases found. Pulmonary tuberculosis was even considered as a leading cause of the death for all age groups in Indonesia (Indonesian Health Research and Development Agency, 2014). The death victims caused by pulmonary tuberculosis is estimated at 61,000 people for each year (Ministry of Health, 2011). Pulmonary tuberculosis brought a lot of harm to the patient both on social and economic aspects. The pulmonary tuberculosis patients were estimated to lose about 3-4 months of their work time which resulting in 20-30 percent decline of household income in one year. In some cases, patients with pulmonary tuberculosis also experienced ostracism by the local community (Aditama, 2005). This indicates that pulmonary tuberculosis was one of the threats to the ideals of the nation, especially in achieving prosperity.

Pulmonary tuberculosis usually occurs in areas with large populations. In Indonesia, about 38 percent of pulmonary tuberculosis cases reported in 2015 occurred in densely populated provinces. The top three were West Java $(59,446)$, East Java $(49,824)$, and Central Java $(39,593)$, where all of which located in Java Island. In addition to these three provinces, other provinces in Java such as Banten, DKI Jakarta, and Yogyakarta also had high rates of pulmonary tuberculosis (Ministry of Health, 2015).

The number of new pulmonary tuberculosis cases belongs to count data. Regression models that can be used to analyze the relationship between the predictor and the response variable in the form of count data are the negative Poisson and Binomial regression model. Poisson regression can be used only in the condition of equidispersion (variance of the response variable equal to its mean) (Cameron \& Trivedi, 2013). However, this assumption is difficult to be fulfilled in reality. The variance of response variable is often greater than its mean (overdispersion). The alternative approach to overcome this overdispersion problem is by using the Binomial Negative Regression (McCullagh \& Nelder, 1989).

Pulmonary tuberculosis-related studies were often associated with spatial aspects such as spatial dependencies and spatial heterogeneity. Spatial dependence can occur because pulmonary tuberculosis is a disease that can be transmitted easily and not limited to the administrative area. This is also in accordance with the law of geography by Tobler (Miller, 2004), which states that "Everything is interrelated. However, the closer will be more related than the far-off". Meanwhile, spatial heterogeneity can occur due to differences in geographical, socio-cultural, and economic conditions that are owned by each region. The development of regression model by considering those spatial aspects is geographically weighted regression (Fotheringham et al., 2002). When this model is applied to the response variable following the Negative Binomial Distribution (Poisson-Gamma) then the development will be Geographically Weighted Negative 
Binomial Regression (GWNBR).

Based on the description above, this research was conducted to model the number of new pulmonary tuberculosis cases for each district / city in Java using GWNBR method. Indahwati and Salamah (2016) conducted a similar modeling in Surabaya using all sub-districts as their unit of analysis. However, the coverage of the area used was still too narrow and the characteristics of the observations were less diverse. Therefore, this research was conducted by using a wider coverage area that was districts/cities in Java Island. In addition, this study also presented a comparison between the GWNBR model and the model generated from other commonly used methods such as negative binomial regression and GWPR.

\section{Methodology}

\subsection{Material and Data}

This research used the secondary data consisting of one response variable and seven predictor variables, with the following details:

Table 1. Research Variables and The Data Source

\begin{tabular}{|c|c|c|}
\hline No. & Variable & Source \\
\hline 1. & $\begin{array}{l}\text { The number of new pulmonary tuberculosis } \\
\text { cases for each district/city in Java in } 2013 \\
\text { (New cases: A case of pulmonary } \\
\text { tuberculosis that occurred during the last } \\
\text { year before the enumeration) ( } Y \text { ) }\end{array}$ & $\begin{array}{l}\text { Publication of Basic Health } \\
\text { Research (Riskesdas) } 2013 \text { for } \\
\text { every Province in Java }\end{array}$ \\
\hline 2. & $\begin{array}{l}\text { Population density of each district/city in } \\
\text { Java in } 2013 \text { (X1) }\end{array}$ & $\begin{array}{l}\text { Provincial Publication in } \\
\text { Figures } 2014 \text { for each province } \\
\text { in Java }\end{array}$ \\
\hline 3. & $\begin{array}{l}\text { The percentage of healthy houses for each } \\
\text { district/city in Java in } 2013 \text { (X2) }\end{array}$ & $\begin{array}{l}\text { Publication of Health Profile } \\
2013 \text { for each province in Java }\end{array}$ \\
\hline 4. & $\begin{array}{l}\text { ef of community health center } \\
\text { as) for each district/city in java in }\end{array}$ & $\begin{array}{l}\text { Provincial Publication in } \\
\text { Figures } 2014 \text { for each province } \\
\text { in Java }\end{array}$ \\
\hline 5. & $\begin{array}{l}\text { The percentage of smokers for each } \\
\text { district/city in Java in } 2013(X 4)\end{array}$ & $\begin{array}{l}\text { Publication of Basic Health } \\
\text { Research (Riskesdas) } 2013 \text { for } \\
\text { every Province in Java }\end{array}$ \\
\hline 6. & $\begin{array}{l}\text { The percentage of households with clean } \\
\text { and healthy behavior (PHBS) for each } \\
\text { district/city in Java in } 2013 \text { (X6) }\end{array}$ & $\begin{array}{l}\text { Publication of Health Profile } \\
2013 \text { for each province in Java }\end{array}$ \\
\hline 7. & $\begin{array}{l}\text { The percentage of people with diabetes } \\
\text { mellitus for each district/city in Java in } 2013 \\
\text { (X5) }\end{array}$ & $\begin{array}{l}\text { Publication of Basic Health } \\
\text { Research (Riskesdas) } 2013 \text { for } \\
\text { every Province in Java }\end{array}$ \\
\hline 8. & $\begin{array}{l}\text { The percentage of people with less IMT } \\
\text { value for each district/city in Java in } 2013 \\
\text { (X7) }\end{array}$ & $\begin{array}{l}\text { Publication of Basic Health } \\
\text { Research (Riskesdas) } 2013 \text { for } \\
\text { every Province in Java }\end{array}$ \\
\hline
\end{tabular}




\section{$2.2 \quad$ Analysis Method}

\section{Poisson Regression}

Poisson regression is a nonlinear regression to model the relationship between response (count) and predictor variables with assumption that response variable $(\mathrm{Y})$ follows Poisson distribution with parameter $\mu$ and $y=0,1,2, \ldots$.

The Poisson distribution has the same mean and variance, as follows:

$$
E(Y)=\operatorname{Var}(Y)=\mu
$$

The link function for Poisson regression is: (McCullagh \& Nelder, 1989)

$$
\eta_{i}=\log \left(\mu_{i}\right)=\boldsymbol{x}_{\boldsymbol{i}}{ }^{T} \boldsymbol{\beta}=\sum_{j=0}^{p} x_{i j} \beta_{j} \text { for } \mathrm{i}=1,2, \ldots, \mathrm{n} \text { and } \mathrm{j}=0,1,2, \ldots, \mathrm{p}
$$

So that Myers (1990) stated Poisson regression model as:

$$
y_{i}=\mu_{i}+\varepsilon_{i}=e^{x_{i}^{T} \boldsymbol{\beta}}+\varepsilon_{i}=e^{\sum_{j=0}^{p} x_{i j} \beta_{j}}+\varepsilon_{i}
$$

with $\varepsilon_{i}$ as an error parameter for the $\mathrm{i}$-th observation and $\mu_{i}$ is the expectation value of $y_{i}$.

\section{Overdispersion}

Indications of overdispersion or underdispersion can be easily found by comparing the mean and variance of the response variables. Overdispersion occurs when the variance is greater than the average (Hilbe, 2011). Furthermore, in Hilbe (2011) also mentioned that overdispersion can be seen by dividing Pearson Chisquare dispersion value or deviance by degrees of freedom. Let $\theta$ be the dispersion parameter of the divison result, then $\theta>1$ means overdispersion, $\theta<1$ means underdispersion, while $\theta=1$ indicates the condition of equidispersion.

\section{Negative Binomial Regression}

According to Hllbe (2011), data with overdispersion can be overcome by involving a parameter derived from gamma distribution in the Poisson model mean. This process will produce a Poisson-Gamma distribution (mix) which similar to the Negative Binomial Distribution. The parameter values of the Poisson-Gamma distribution are expressed in the form of $\mu=\alpha \beta$ and $\theta=1 / \alpha$ so the mean and variance can be stated as:

$$
E[Y]=\mu \text { and } V[Y]=\mu+\theta \mu^{2}
$$

The Binomial Negative density function will be:

$$
f(y ; \mu, \theta)=\frac{\Gamma(y+1 / \theta)}{\Gamma(y+1) \Gamma(1 / \theta)}\left(\frac{1}{1+\theta \mu}\right)^{\frac{1}{\theta}}\left(\frac{\theta \mu}{1+\theta \mu}\right)^{y}
$$

Where $y=0,1,2, \ldots$ and $\theta \geq 0$

Negative Binomial Regression model belongs to the Generalized Linear Model (GLM) group, so that in the estimation of the model coefficient parameter, the predictor variable can be written trough a linear combination with the natural logarithm link function as follows: (Hilbe, 2011).

with $\mathrm{i}=1,2, \ldots, \mathrm{n}$ and $\mathrm{j}=0,1,2, \ldots, \mathrm{k}$

$$
g\left(\mu_{i}\right)=\ln \left(\mu_{i}\right)=\boldsymbol{x}_{\boldsymbol{i}}^{T} \boldsymbol{\beta}=\sum_{j=1}^{k} x_{i j} \beta_{j}
$$


In the form of regression it can be written as:

$$
y_{i}=\exp \left(\boldsymbol{x}_{\boldsymbol{i}}^{T} \boldsymbol{\beta}\right)+\varepsilon_{i}=\exp \left(\sum_{j=1}^{k} x_{i j} \beta_{j}\right)+\varepsilon_{i}
$$

With $\boldsymbol{x}_{i}$ as a vector of predictor variable, $\boldsymbol{\beta}$ as a vector of regression coefficient, and $\varepsilon_{i}$ as an error parameter of the $i$-th observation.

\section{Spatial Dependency}

Spatial dependency testing is performed to see if the observations at one location affect the observations in other adjacent locations. In general, inter-regional linkages can be measured using Moran's Index statistics. According to Anselin (1995), statistical tests that can be used to determine the existence of spatial dependence is Moran's Index test with the following hypothesis:

$H_{0}: I=0$ (No spatial dependency)

$H_{1}: I \neq 0$

Test statistics:

$$
\mathrm{Z}_{\text {hit }}=\frac{\hat{\mathrm{I}}-\mathrm{E}(\hat{\mathrm{I}})}{\sqrt{\operatorname{Var}(\hat{\mathrm{I}})}}
$$

With $I, E(\hat{I})$, and $\operatorname{Var}(\hat{I})$ as the Moran's index value, expected value, and variance. I can be written as the following:

$$
\hat{I}=\frac{n \sum_{i=1}^{n} \sum_{j=1}^{n} w_{i j}\left(y_{i}-\bar{y}\right)\left(y_{j}-\bar{y}\right)}{\left(\sum_{i=1}^{n} \sum_{j=1}^{n} w_{i j}\right) \sum_{i=1}^{n}\left(y_{i}-\bar{y}\right)^{2}}
$$

Where:

$\mathrm{n} \quad$ : number of observations

$\bar{y} \quad$ : mean value of $y_{i}$ from $\mathrm{n}$ locations

$y_{i} \quad$ : observations value at the $\mathrm{i}$-th location

$y_{j} \quad$ : observations value at the j-th location

$w_{i j}$ : the element of spatial weighting matrix

Decline $H_{0}$ if $\left|Z_{\text {hit }}\right|>Z_{\alpha / 2}$, which means that there are spatial dependencies between response variables for each observation.

\section{Spatial Heterogeneity}

Characteristic differences between one observation point and other observation point lead to the spatial heterogeneity, so that the resulting regression parameters may vary. According to Anselin (1998), testing of spatial heterogeneity can be done using Breusch-Pagan with the following hypothesis:

$H_{0}:{\sigma_{1}}^{2}=\sigma_{2}{ }^{2}=\cdots=\sigma_{n}{ }^{2}=\sigma^{2}$ (Spatial homogeneity)

$H_{1}$ : At least one $\sigma_{i}^{2} \neq \sigma^{2}$

Breusch-Pagan (BP) test statistics:

where:

$$
B P=(1 / 2) \boldsymbol{f}^{T} \boldsymbol{Z}\left(\boldsymbol{Z}^{T} \boldsymbol{Z}\right)^{-1} \boldsymbol{Z}^{T} \boldsymbol{f}
$$

$\mathbf{f}=\left(f_{1}, f_{2}, \ldots, f_{n}\right)^{T}$ with $f_{i}=\left(\frac{e_{i}^{2}}{\sigma^{2}}-1\right)$

$e_{i}=y_{i}-\hat{y}_{l}$

$e_{i}^{2} \quad$ : error square of the $\mathrm{i}$-th observation 
$\boldsymbol{Z}$ : an $\mathrm{n}(\mathrm{k}+1)$ matrix containing a normally-standardized vector $(\mathrm{z})$ for each observation

$\sigma^{2}$ : variance of $y$

Reject $H_{0}$ if $B P>\chi_{\alpha, p}^{2}$ or $p$-value $<\alpha$, which indicates that spatial heterogeneity occurs in the model.

\section{Spatial Weights Function}

According to Fotheringham, et al (2002), the formation of a spatial weights matrix can be performed using two kernel functions based on its bandwidth, that are the fixed and adaptive kernel function.

1. Fixed Kernel Function

This approach is suitable to be applied to the area with adjacent locations and less suitable to be applied to areas with remote locations. In this function, one optimum bandwidth value is applied to the whole area of observation.

- Fixed Gaussian Kernel Function

$$
w_{i j}=\exp \left[-\frac{1}{2}\left(\frac{d_{i j}}{b}\right)^{2}\right]
$$

- $\quad$ Fixed Bi-square Kernel Function

$$
w_{i j}=\left\{\begin{array}{c}
{\left[1-\left(\frac{d_{i j}}{b}\right)^{2}\right]^{2}, \text { if } d_{i j}<b} \\
0, \text { others }
\end{array}\right.
$$

2. Adaptive Kernel Function

On the adaptive kernel function, optimum bandwidth is enforced based on the nearest neighbors. This functionality applies relatively small bandwidth to adjacent areas and relatively large bandwidth in remote areas.

The adaptive kernel function can be divided into two following functions:

- Adaptive Gaussian Kernel Function

$$
\mathrm{w}_{\mathrm{ij}}=\exp \left[-\frac{1}{2}\left(\frac{\mathrm{d}_{\mathrm{ij}}}{\mathrm{b}_{\mathrm{i}(\mathrm{q})}}\right)^{2}\right]
$$

- $\quad$ Adaptive Bi-square Kernel Function

$$
w_{i j}=\left\{\begin{array}{c}
{\left[1-\left(\frac{d_{i j}}{b_{i(q)}}\right)^{2}\right]^{2}, \text { if } d_{i j}<b_{i(q)}} \\
0, \text { others }
\end{array}\right.
$$

The $d_{i j}$ value used is the euclidean distance between location $\left(u_{i}, v_{i}\right)$ and location $\left(u_{j}, v_{j}\right)$ which are calculated by the following equation:

$$
d_{i j}=\sqrt{\left(u_{i}-u_{j}\right)^{2}+\left(v_{i}-v_{j}\right)^{2}}
$$

Adjustment on bandwidth can change the free degrees in the model so that the resulting model may vary. One strategy that can be used to overcome this problem is to find the kernel function that can minimize Akaike Information Criterion (AIC), with the following formula (Gill, 2001):

$$
A I C=-2 l(\hat{\theta} \mid y)+2 p
$$


Where $\mathrm{I}(\widehat{\theta} \mid y)$ is the maximum value from log-likelihood model and $p$ is the number of parameters in the model including the constant.

\section{Geographically Weighted Poisson Regression (GWPR)}

GWPR is a development model of Poisson regression with local parameter estimator and the assumption of Poisson-distributed data. In this model the regression coefficients are influenced by the geographic location symbolized as $\left(u_{i}, v_{i}\right)$ being the location where the data is observed. The GWPR model can be described as follows:

$y_{i} \sim$ Poisson $\left(u_{i}\right)$, where $E\left[y_{i}\right]=\widetilde{\mu_{l}}=\exp \left(\sum_{j=0}^{p} \beta_{j}\left(u_{i}, v_{i}\right) x_{i j}\right)$, for $\mathrm{i}=1,2, \ldots, \mathrm{n}$ and $j=1,2, \ldots, p$

with:

$k \quad$ : number of predictor variables

$y_{i} \quad:$ the response value of the i-th observation

$x_{i j} \quad:$ the observation value of the k-th predictor variable at the observation coordinate $\left(u_{i}, v_{i}\right)$

$\beta_{j}\left(u_{i}, v_{i}\right)$ : regression coefficient of the $\mathrm{j}$-th predictor variable at the observation coordinate $\left(u_{i}, v_{i}\right)$

$\left(u_{i}, v_{i}\right) \quad$ : the latitude and longitude coordinates of the $\mathrm{i}$-th point at a geographic location

\section{Geographically Weighted Negative Binomial Regression (GWNBR)}

The GWNBR model is a method used to model data counts that have spatial dependency and heterogeneity when overdispersion occurs in the data. This model will provide different local parameter estimates for each location. GWNBR is an extension of a global model that allows spatial variation of parameters $\beta_{k}$ and $\theta$. The local model of GWNBR can be written as follows (Da Silva, 2013):

$$
y_{i} \sim N B\left[\exp \left(\sum_{j} \beta_{j}\left(u_{i}, v_{i}\right) x_{i j}\right), \theta\left(u_{i}, v_{i}\right)\right] \text { with } \mathrm{i}=1,2, \ldots, \mathrm{n}
$$

Where $\left(u_{i}, v_{i}\right)$ is the coordinate of $\mathrm{i}$-th observation. In regression form can be written as follows:

$$
E\left[y_{i}\right]=\widehat{\mu}_{\imath}=\exp \left\{\left(\beta_{0} u_{i}, v_{i}\right)+\sum_{j} \beta_{j}\left(u_{i}, v_{i}\right) x_{i j}+\theta\left(u_{i}, v_{i}\right)\right\}
$$

Where :

$y_{i} \quad:$ the value of the i-th observation

$x_{i j} \quad:$ the observation value of the k-th predictor variable at the observation coordinate $\left(u_{i}, v_{i}\right)$

$\beta_{j}\left(u_{i}, v_{i}\right)$ : regression coefficient of the $\mathrm{j}$-th predictor variable at the observation coordinate $\left(u_{i}, v_{i}\right)$

$\theta\left(u_{i}, v_{i}\right)$ : dispersion parameter of location $\left(u_{i}, v_{i}\right)$

The presence of spatial heterogeneity causes variations in response and predictor variables so that a spatial weighing function can be obtained by utilizing kernel functions. Weighted log-likelihood functions are as follows: 


$$
\begin{aligned}
\ln L(.)= & \sum_{i=1}^{n} w_{i j}\left(u_{i}, v_{i}\right)\left[\ln \frac{\Gamma\left(y_{i}+1 / \theta_{i}\right)}{\Gamma\left(1 / \theta_{i}\right) \Gamma\left(y_{i}+1\right)}+y_{i} \ln \left(\theta_{i} \mu_{i}\right)-\left(1 / \theta_{i}+\right.\right. \\
& \left.\left.y_{i}\right) \ln \left(1+\theta_{i} \mu_{i}\right)\right]
\end{aligned}
$$

With $L()=.L\left(\boldsymbol{\beta}\left(u_{i}, v_{i}\right), \theta_{i} \mid x_{i j}, y_{i}\right)$ and $\mu_{i}=\exp \left(\boldsymbol{x}_{i}^{\prime} \boldsymbol{\beta}\left(\boldsymbol{u}_{\boldsymbol{i}}, \boldsymbol{v}_{\boldsymbol{i}}\right)\right)$

Parameter estimation process is done by using the MLE method with NewtonRaphson numeric iteration. This method will use the information from Hessian matrix until the results are convergent.

\section{GWNBR Model Parameter Test}

Parameter testing can be done either simultaneously or partially. Simultaneous test aims to see whether or not all predictor variables influence the response variable together. The test hypothesis used is:

$H_{0}: \beta_{1}\left(u_{i}, v_{i}\right)=\beta_{2}\left(u_{i}, v_{i}\right)=\beta_{3}\left(u_{i}, v_{i}\right)=\ldots=\beta_{k}\left(u_{i}, v_{i}\right)=0$

$H_{1}:$ at least one $\beta_{j}\left(u_{i}, v_{i}\right) \neq 0$, for $\mathrm{j}=1,2, \ldots, \mathrm{k}$

Test Statistic:

$$
G=-2 \ln \left[\frac{L(\widehat{\omega}}{L(\widehat{\Omega}}\right] \sim \chi_{(k)}^{2}
$$

$L(\widehat{\omega})$ is a likelihood value for a set of parameter under $H_{0}$ (intercept only), while $L(\widehat{\Omega})$ is a likelihood value for the model with all predictor variables in. The decision will be taken is reject $H_{0}$ if $\mathrm{G}>\chi_{(\alpha, k)}^{2}$, which indicates that there is at least one of GWNBR parameter that has a significant effect on the response variable.

Partial test is done to know which parameter have a significant effect to the response variable in each location. Testing parameters GWNBR model partially using the z-score test with the following hypothesis:

$H_{0}: \beta_{j}\left(u_{i}, v_{i}\right)=0$, for $\mathrm{j}=1,2, \ldots, \mathrm{k}$

$H_{1}: \beta_{j}\left(u_{i}, v_{i}\right) \neq 0$

Test statistics:

$$
Z=\frac{\widehat{\beta}_{j}\left(u_{i}, v_{i}\right)}{\operatorname{se}\left(\widehat{\beta}_{j}\left(u_{i}, v_{i}\right)\right)} \sim \mathrm{N}(0,1)
$$

With $\hat{\beta}_{j}\left(u_{i}, v_{i}\right)$ is the estimated parameter $\beta_{j}\left(u_{i}, v_{i}\right)$ and $\operatorname{se}\left(\hat{\beta}_{j}\left(u_{i}, v_{i}\right)\right)$ is the estimated standard error from diagonal element of covariance $\left(\hat{\beta}_{j}\left(u_{i}, v_{i}\right)\right)$ matrix. Reject $H_{0}$ if $\left|Z_{\text {hitung }}\right|>Z_{\alpha / 2}$ which indicates that parameter $\beta_{j}\left(u_{i}, v_{i}\right)$ has significant effect on the response variable.

\section{GWNBR Model Evaluation}

Model evaluation is conducted to find out which model is more effective to model the response variable. Evaluation is done by comparing the model based on deviance value and AIC. According to Gill (2001) model evaluation based on deviance can use the following equation:

$$
\begin{aligned}
D & =-2 \ln \left[\frac{L\left(y \mid \hat{\beta}^{*}\left(u_{i}, v_{i}\right)\right.}{L(y \mid \hat{\mu})}\right] \\
& =2 \sum_{i=1}^{n}\left[y_{i} \ln \left(\frac{y_{i}}{\widehat{\mu}_{i}\left(u_{i}, v_{i}\right)}\right)+\left(1+y_{i}\right) \ln \left(\frac{1+\widehat{\mu}_{i}\left(u_{i}, v_{i}\right)}{1+y_{i}}\right)\right]
\end{aligned}
$$


With In $L\left(y \mid \hat{\beta}^{*}\left(u_{i}, v_{i}\right)\right.$ as a natural logarithm of the model estimation without involving the predictor variable at location i and $\ln L(y \mid \hat{\mu})$ as a natural logarithm of the model estimation by involving all the predictor variables at location $\mathrm{i}$. The smaller the deviance value the less error generated by the model (McCullagh \& Nelder, 1989).

In addition to deviance, Akaike Information Criterion (AIC) is often used as a criterion in determining the best model. Basically the best model is a model that minimizes the sum of the negative likelihood values and the number of parameters used (AIC).

\section{Results and Discussion}

\subsection{Characteristics and Distribution Pattern of The Number of New Pulmonary Tuberculosis Cases in Java in 2013}

Transmission of pulmonary tuberculosis that could occur easily caused the disease was often associated with other factors, whether environmental factors, behavior, and individual immunity itself. Table 1 presented the descriptive statistics of the number of new pulmonary tuberculosis cases and the variables suspected to be influential.

Table 2. Descriptive Statistics of The Number of New Pulmonary Tuberculosis Cases in Java in 2013 and Related Variables

\begin{tabular}{|c|c|c|c|c|c|c|}
\hline Variable & Mean & Min & Q1 & Median & Q3 & Max \\
\hline$(1)$ & (2) & (3) & (4) & (5) & (6) & (7) \\
\hline $\begin{array}{l}\text { The number of new } \\
\text { pulmonary tuberculosis } \\
\text { cases }\end{array}$ & 512 & 0 & 128 & 265.5 & 609 & 3641 \\
\hline Population density (x1) & 3095.7 & 364 & 716.5 & 1037.5 & 3309.2 & 18836.5 \\
\hline $\begin{array}{l}\text { Percentage of healthy } \\
\text { houses }(x 2)\end{array}$ & 64.9 & 21.06 & 54.88 & 66 & 75 & 100 \\
\hline $\begin{array}{l}\text { The number of community } \\
\text { health center (Puskesmas) } \\
\text { (x3) }\end{array}$ & 116.76 & 8 & 75.25 & 102.5 & 128 & 666 \\
\hline Percentage of smokers (x4) & 29.36 & 18.7 & 26.73 & 28.9 & 32.55 & 39 \\
\hline $\begin{array}{l}\text { Percentage of the household } \\
\text { with clean and healthy } \\
\text { behavior (x5) }\end{array}$ & 40.95 & 12.1 & 31.23 & 40.95 & 50.27 & 77.2 \\
\hline $\begin{array}{l}\text { Percentage of people with } \\
\text { Diabetes Mellitus (x6) }\end{array}$ & 1.733 & 0.5 & 1.2 & 1.5 & 2.075 & 4.8 \\
\hline $\begin{array}{l}\text { Percentage of people with } \\
\text { less IMT value }(x 7)\end{array}$ & 11.21 & 6 & 10.13 & 11 & 12.52 & 15.68 \\
\hline
\end{tabular}




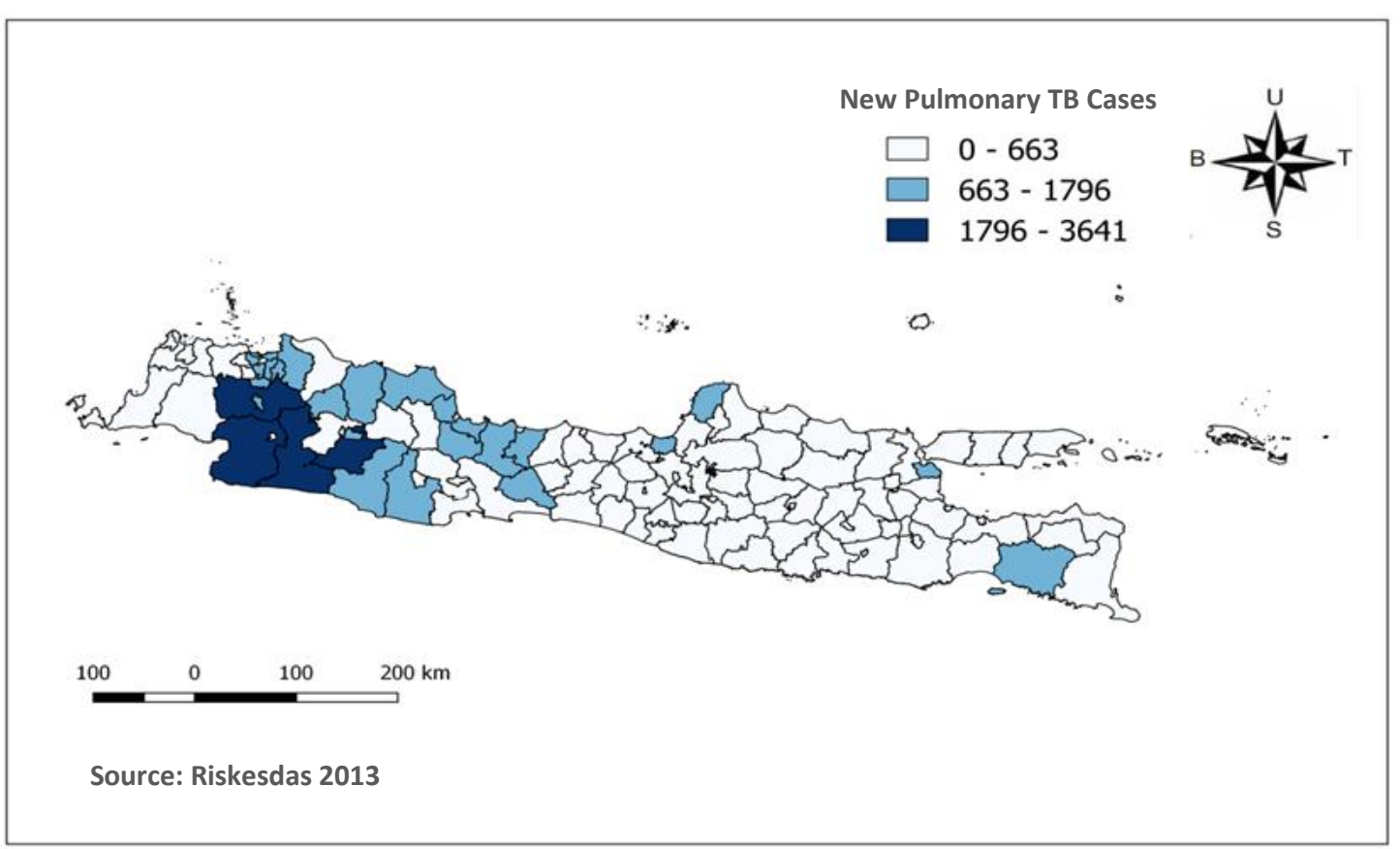

Figure 1. Distribution Map of The Number of New Pulmonary Tuberculosis Cases in Java in 2013.

The diversity of regional characteristics owned by each district/city causes the number of new pulmonary tuberculosis cases found to be various as well. In Figure 1 above, a map of the new pulmonary tuberculosis cases distribution for each district/city in Java was presented.

In 2013, there were found about 60,411 new pulmonary tuberculosis cases in Java with the most cases occurred in Bogor regency which reached 3,641 cases. Meanwhile, there were four regencies / cities with zero new cases such as Pamekasan Regency, Bondowoso Regency, Surakarta City, and Blitar City. This might happen because the data collection was done by survey so that new pulmonary tuberculosis cases could not be collected as a whole.

\subsection{Overdispersion}

Before conducting dispersion testing, multicollinearity assumption checks were necessary to select the variables to be used. Violations on this assumption of multicollinearity would cause standard deviation of the regression coefficients to be insignificant, making it difficult to separate the influence of each independent variable. Multicollinearity checks were performed using the Variance Inflation Factor (VIF) value. The result of the examination showed that there was no predictor variable that had VIF value more than 5. It meant there was no significant linear relationship between the predictor variable so that this assumption was fulfilled and the seven predictor variables could be used in the analysis.

Then, dispersion testing was done by using Rstudio 3.3.2 program. The result showed that with $Z_{0.05}=5.7469$ and $p$-value of $4.545 \mathrm{e}-09$, the null hypothesis would be rejected. The conclusion was there was overdispersion in the data with dispersion 
parameter of 382.0079 . Those situation caused the Poisson regression to be no longer suitable for modeling the data because the estimated parameters generated would be biased.

\subsection{Modeling The Number of New Pulmonary Tuberculosis Cases with Negative Binomial Regression}

The regression model that could be used to model the overdispersed data count was the Binomial Negative regression. Here were the results of modeling the number of new pulmonary tuberculosis cases with negative binomial regression.

Table 3. Negative Binomial Regression Model of The Number of New Pulmonary Tuberculosis Cases

\begin{tabular}{|c|c|c|c|c|}
\hline Variable & Estimate & Std.Error & z value & $\operatorname{Pr}(>|z|)$ \\
\hline$(1)$ & $(2)$ & (3) & $(4)$ & $(5)$ \\
\hline Intercept & 5.012E-01 & $1.29 \mathrm{E}+00$ & 0.388 & 0.6978 \\
\hline Population density (x1) & $1.283 \mathrm{E}-05$ & 2.56E-05 & 0.502 & 0.6158 \\
\hline Percentage of healthy houses $(x 2)$ & $-1.144 \mathrm{E}-02$ & 7.07E-03 & -1.618 & 0.1057 \\
\hline $\begin{array}{l}\text { The number of community health } \\
\text { center (Puskesmas) (x3) }\end{array}$ & $5.070 \mathrm{E}-03$ & $9.89 \mathrm{E}-04$ & 5.129 & $0.0000^{*}$ \\
\hline Percentage of smokers (x4) & $0.1002 E-01$ & $2.62 \mathrm{E}-02$ & 3.818 & $0.0001^{*}$ \\
\hline $\begin{array}{l}\text { Percentage of the household with } \\
\text { clean and healthy behavior (x5) }\end{array}$ & $1.885 \mathrm{E}-02$ & 8.37E-03 & 2.251 & $0.0244^{*}$ \\
\hline $\begin{array}{l}\text { Percentage of people with Diabetes } \\
\text { Mellitus (x6) }\end{array}$ & $01.496 \mathrm{E}-01$ & $1.45 \mathrm{E}-01$ & 1.035 & 0.3006 \\
\hline $\begin{array}{l}\text { Percentage of people with less IMT } \\
\text { value }(x 7)\end{array}$ & $1.441 \mathrm{E}-01$ & 4.63E-02 & 3.112 & $0.0019^{*}$ \\
\hline
\end{tabular}

Note: $\left.{ }^{*}\right)$ Significant at the significance level of $5 \%$

The table above showed that at the 0.05 significance level, the number of community health centers, the percentage of smokers, the percentage of households with clean and healthy behavior, and the percentage of people with less IMT value were not significantly affecting the number of new pulmonary tuberculosis cases.

\subsection{Spatial Aspects Test}

According to McCullagh and Nelder (1989), overdispersion could occur because of clustering in the population. Therefore, it was necessary to do spatial testing between observations. There were two tests to be performed: spatial dependency test and spatial heterogeneity test. The result of spatial dependency test with GeoDa showed the index Moran value of new pulmonary tuberculosis cases was 0.3726 . That value was tested with a permutation of 999 times and gave a result $Z_{\text {hit }}=9.5556$ with $p$-value of 0.001 . Therefore, with a significance level of 0.05 it could be concluded that there were spatial dependencies between observation areas. 
Next was the heterogeneity test performed by Breusch Pagan test. By using the Rstudio 3.3.2, statistical value of Breusch Pagan test resulted was 34.758 with pvalue $=4.802 \mathrm{e}-06$. Thus, at the level of significance of 0.05 it could be concluded that there is spatial heterogeneity between observation areas.

\subsection{Modeling The Number of New Pulmonary Tuberculosis Cases with GWNBR}

Modeling with Geographically Weighted Negative Binomial Regression began by calculating the spatial weights matrix. To obtain a spatial weights matrix, the bandwidth must first be determined. Determination of bandwidth was done by Golden Section Search technique. Bandwidth calculations required a matrix of distance between districts/cities. The distance used in this study was Euclidean distance with the selected bandwidth value was 101.82. The euclidean distance and bandwidth generated were then used to calculate the spatial weights matrix. Spatial weights matrix calculation was performed by using the Fixed Gaussian kernel function because it produced the smallest AIC value.

After the spatial weights matrix was obtained, the next step was modeling using GWNBR. To obtain a convergent parameter, iteration was done 20 times for each region. The GWNBR model generated 944 coefficients estimates $\left(\widehat{\beta}_{j}\left(u_{i}, v_{i}\right)\right)$ for 118 districts/cities in Java. The coefficient determined the magnitude of the changes in the response variables for each change of the predictor variables.

Furthermore, simultaneous testing was done by comparing the deviance model of GWNBR with $\chi_{(7,0.05)}^{2}=14.067$. The deviance value of GWNBR model was 59.002. Because the deviance value was greater, then with a significance level of 0.05 it could be concluded that at least one of GWNBR parameter was significant in the model. After simultaneous testing was done, it was necessary to test partially to know which parameters were significant in the model. The partial test result showed that with significance level of 0.05 it could be concluded that not all local parameter coefficients were significant in the model. For example, the following model would be shown for Indramayu Regency (Regency/City Code: 3212):

$$
\begin{gathered}
\hat{\mu}_{3212}=\exp \left(0.2808^{*}-0.0000177 x_{1}-0.00619 x_{2}+0.004521 x_{3}+0.113298 x_{4}{ }^{*}\right. \\
\left.-0.01552 x_{5}+0.140496 x_{6}{ }^{*}+0.141361 x_{7}{ }^{*}+1.142317^{*}\right)
\end{gathered}
$$

Note: *) significant at the significance level of $5 \%$

Based on the model above it was known that the intercept coefficient and dispersion parameters (theta) were significant in the model. Intercept value of 0.2808 showed that when other variables were zero then the number of new pulmonary tuberculosis cases in Indramayu district was $\mathrm{e}^{0.2808} \sim 1$ case. While the theta value of 1.142317 indicated an overdispersion in the data.

In addition, it also could be seen from the model that there were three significant predictor variables at the 0.05 significance level. For the percentage of smokers variable, it could be interpreted that every one percent increase of smokers, the number of new pulmonary tuberculosis cases would increase as much as $e^{0.113298}=$ 1.11996 times assuming that other variables were constant. Then for the percentage of people with diabetes mellitus, it could be interpreted that every one percent increase of people with diabetes mellitus, the number of new pulmonary tuberculosis 
cases would increase as much as $e^{0.140496}=1.15084$ times assuming that other variables were constant. The last for the percentage of people with less IMT value. it could be interpreted that every one percent increase of people with less IMT value. the number of new pulmonary tuberculosis cases would increase as much as $e^{0.141361}=1.1518$ times assuming that other variables were constant.

\subsection{Grouping Areas}

Modeling using GWNBR resulted the different parameter coefficients and $Z_{\text {hitung }}$ for each region. This allowed a variable to has a significant effect in a particular area but was not significant in other regions. Therefore, grouping of regions based on significant variables needed to be done to identify areas with similar characteristics. Here were the grouping of regions based on significant variables.

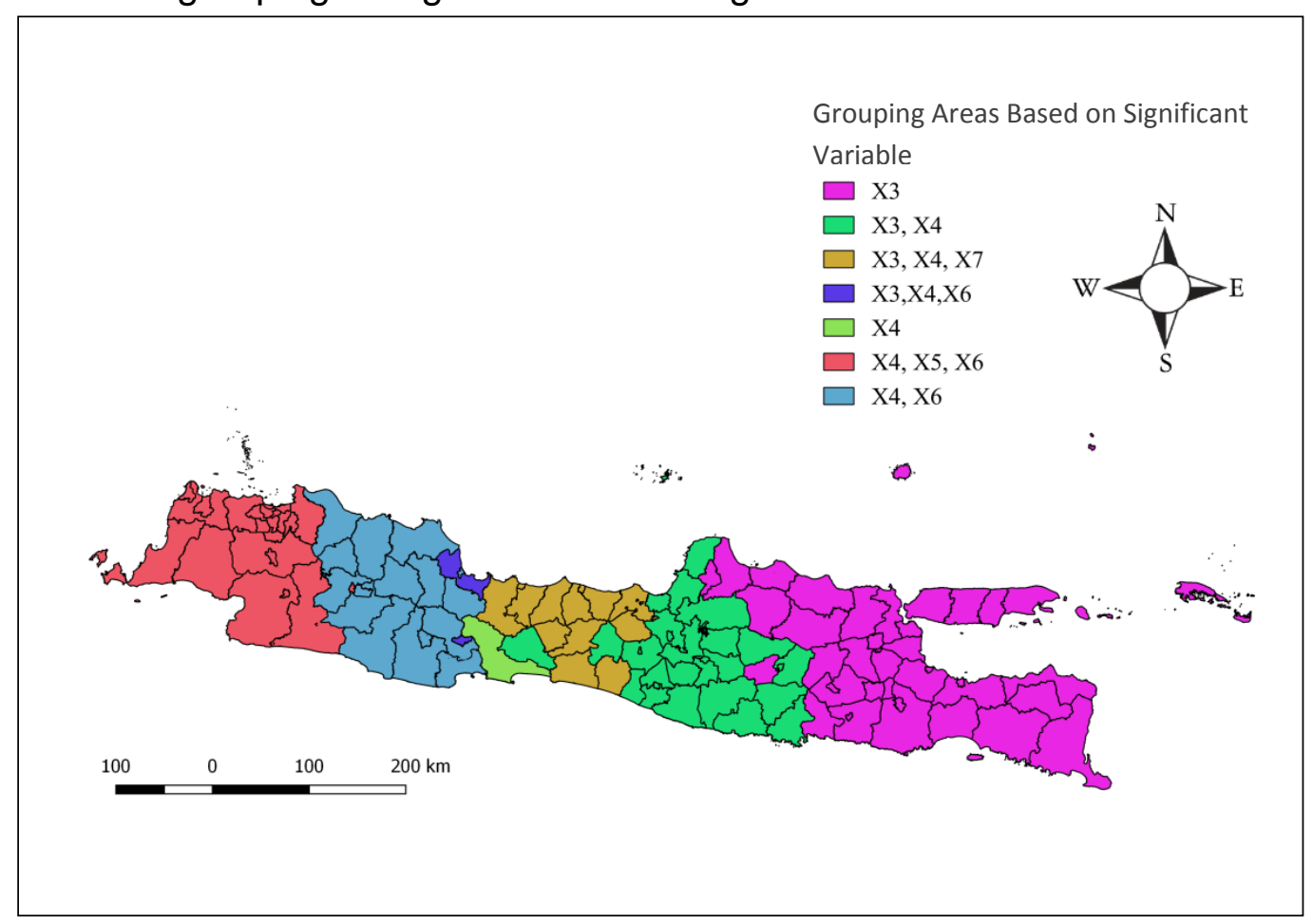

Figure 2. Grouping Areas Based on Significant Variable

From the picture above could be seen that there were seven groups of districts/cities that were formed. The districts/cities in Banten, DKI Jakarta, and some of West Java entered in group 6 with three significant variables: percentage of smokers, percentage of households with clean and healthy behavior, and percentage of people with diabetes mellitus. While the district /cities in East Java and some districts/cities in Central Java entered in group 1 with only one significant variable that is the number of community health center. It also could be seen that only Cilacap regency that entered in group 5 with only one significant variable that is the percentage of smokers. Not only group 5, group 4 also only consisted of two areas, namely Cirebon regency and Banjar city. 


\subsection{Fitting the GWPR Model}

Data count modeling by considering spatial aspects could also be done using GWPR method with the assumption that there was no overdispersion in the data. The result of modeling using GWR4 showed that the parameter coefficient of GWPR model had negative to positive value ranges for six variables. That meant there were some areas with the parameter coefficients that were contrary to the theories already proposed. Table 4 showed a summary of the results.

Table 4. Summary of Modeling Results of New Pulmonary Tuberculosis Cases by GWPR

\begin{tabular}{|c|c|c|c|c|c|c|}
\hline Variable & Mean & Min & Q1 & Median & Q3 & Max \\
\hline (1) & (2) & (3) & (4) & (5) & (6) & (7) \\
\hline Intercept & 3.718 & 1.679 & 2.377 & 3.465 & 5.038 & 6.761 \\
\hline Population density (x1) & $-1.743 \mathrm{E}-05$ & $-2.86 E-04$ & $-2.70 \mathrm{E}-05$ & $-2.50 \mathrm{E}-06$ & 3.05E-05 & 7.50E-05 \\
\hline $\begin{array}{l}\text { Percentage of healthy } \\
\text { houses (x2) }\end{array}$ & -0.009522 & -0.025637 & -0.019466 & -0.007899 & -0.001043 & 0.013229 \\
\hline $\begin{array}{l}\text { The number of } \\
\text { community health } \\
\text { center (Puskesmas) } \\
\text { (x3) }\end{array}$ & 0.009047 & 0.002214 & 0.002452 & 0.009979 & 0.013909 & 0.017338 \\
\hline $\begin{array}{l}\text { Percentage of smokers } \\
(x 4)\end{array}$ & 0.032153 & -0.026991 & -0.005687 & 0.011135 & 0.091427 & 0.119402 \\
\hline $\begin{array}{l}\text { Percentage of the } \\
\text { household with clean } \\
\text { and healthy behavior } \\
\text { (x5) }\end{array}$ & -0.0004828 & -0.040262 & -0.025583 & -0.016926 & 0.032164 & 0.039149 \\
\hline $\begin{array}{l}\text { Percentage of people } \\
\text { with Diabetes Mellitus } \\
\text { (x6) }\end{array}$ & 0.2606 & -0.1062 & 0.1390 & 0.2277 & 0.4432 & 0.5277 \\
\hline $\begin{array}{l}\text { Percentage of people } \\
\text { with less IMT value }(x 7)\end{array}$ & 0.02504 & -0.06686 & -0.0110 & 0.01509 & 0.07974 & 0.14351 \\
\hline
\end{tabular}

\subsection{Evaluation of GWNBR Model}

Evaluation of GWNBR model was done by comparing the AIC and deviance value generated from GWNBR model with the AIC and deviance value generated from negative binomial regression and GWPR model. The best model was the model that produces the smallest AIC and deviance value. The following table showed the AIC and deviance value comparison between those three models. 
Table 5. AIC and Deviance Value of Negative Binomial Regression, GWPR, and GWNBR Model

\begin{tabular}{|c|c|c|}
\hline Regression Model & AIC & Deviance \\
\hline $\mathbf{( 1 )}$ & $\mathbf{( 2 )}$ & $\mathbf{( 3 )}$ \\
\hline Negative Binomial Regression & 1664.1 & 138.39 \\
\hline GWPR & 16919.07 & 16856.86 \\
\hline GWNBR & 1478.474 & 59.002 \\
\hline
\end{tabular}

It could be seen in Table 5 that the GWNBR model had smaller AIC and deviance values than other models. Therefore, it could be said that GWNBR method was better for modeling the number of new pulmonary tuberculosis cases in Java.

\section{Conclusion and Suggestion}

In 2013 there were found about 60,411 new cases of pulmonary tuberculosis in Java, with most cases found in Bogor district. In general, the distribution of those cases was not varied but forming certain groupings.

Modeling using GWNBR showed that with the significance level of 0.05 it could be concluded that the number of community health center and the percentage of smokers had a positive and significant influence in most districts. The percentage of households with clean and healthy behavior had a negative and significant influence in a small number of districts/cities (34.47\%). While the percentage of people with diabetes mellitus and percentage of people with less IMT value had a positive and significant influence in a small number of districts/cities. Meanwhile, population density and percentage of healthy houses were not significant in the model for each district /city.

Over all, GWNBR method was better to model the overdispersed count data that had the spatial dependency and heterogeneity (in this case is the number of new pulmonary tuberculosis cases) than negative binomial regression and GWPR method. The further research can use other independence variables which has not been used in this research. Also, it is necessary to examine whether there are any specific spatial effect measurements for the count data.

\section{References}

Aditama, Y. (2005). Tuberkulosis dan Kemiskinan. Majalah Kesehatan Indonesia, 55(2), 49-51.

Anselin, L. (1995). Local Indicators of Spatial Association-LISA. Geographical Analysis, 27 (2), 93-115.

Anselin, L. (1988). Spatial Econometric Methods and Model. Dordrecht: Kluwer Academic Publishers.

Badan Penelitian dan Pengembangan Kesehatan Indonesia. (2014). Hasil Sample Registration Survey. Jakarta: Balitbangkes. 
Cameron, A., \& Trivedi, P. (2013). Regression Analysis of Count Data (Second ed). Cambridge: Cambridge University Press.

Da Silva, A. \& Rodrigues, T. (2013). Geographically Weighted Negative Binomial Regression: Incorporating Overdispersion. New York: Springer.

Fotheringham, A. S., Brunsdon, C., \& Charlton, M. (2002). Geographically Weighted Regression. Inggris: University of Newcastle.

Gill, P. J. (2001). Generalized Linear Models: A Unified Approach. California: Sage Publication, Inc.

Hilbe, J. (2011). Negative Binomial Regression (2nd ed). New York: Cambridge University Press.

Indahwati, S. D. (2016). Analisis Faktor-Faktor yang Memengaruhi Jumlah Kasus Tuberkulosis di Surabaya Tahun 2014 Menggunakan Geographically Weighted Negative Binomial Regression. Jurnal Sains dan Seni ITS, 5(2), 193-197.

Kementerian Kesehatan Rl. (2011). Strategi Nasional Pengendalian Tb di Indonesia Tahun 2010-2014. Jakarta: Kementerian Kesehatan RI.

McCullagh, P., \& Nelder, J. (1989). Generalized Linear Models (Second ed). London: Chapman and Hall.

Miller, H. (2004). Tobler's First Law and Spatial Analysis. Annalys of the Association of American Geographers, 94(2), 284-289.

Myers, R. (1990). Classical and Modern Regression with Application Second Edition. New York: PWS-KENT.

Ramadhan, R. F. (2016). Pemodelan Data Kematian Bayi dengan Geographically Weighted Negative Binomial Regression. Media Statistika, 9(2), 95-106.

Suarni, H. (2009). Faktor Risiko yang Berhubungan dengan Kejadian Penderita Penyakit TB Paru BTA Positif di Kecamatan Pancoran Mas Kota Depok Bulan Oktober Tahun 2008-April Tahun 2009 [Skripsi] . Depok: FKM UI.

Widarjono, A. (2007). Ekonometrika Teori dan Aplikasi untuk Ekonomi dan Bisnis. Yogyakarta: Ekonosia FE UII.

Widoyono. (2008). Penyakit Tropis: Epidemiologi, Penularan, Pencegahan, dan Pemberantasannya. Jakarta: Erlangga.

World Health Organization. (2016). Global Tuberculosis Report. Jenewa: WHO. 